\title{
Potency of garlic juice supplementation on some physiological and immunological aspects of broilers exposed to heat stress
}

\author{
H.A.J. Al-Shwilly \\ Department of Animal Resources, College of Agriculture, University of Sumer, Iraq \\ Email: dr.hatim77@yahoo.com. Tel:009647832049050
}

(Received September 7, 2017; Accepted September 26, 2017)

\begin{abstract}
The current study aimed to investigate the effect of garlic juice supplementation with broiler drinking water on performance, immune response, lipid profile, blood picture and activity of liver enzymes under heat stress. For this purpose 100 four days aged broiler checks (Ross) were allocated into control (C) and three treatment groups (25 each). All group checks were housed at $5{ }^{\circ} \mathrm{C}$ above normal ambient temperature during the experiment. Treatment groups (T1, T2 and T3) checks were supplemented with $0.5,1$ and $1.5 \mathrm{ml} / \mathrm{L}$, respectively, with garlic juice in drinking water ( $6 \mathrm{hrs}$ a day). Food and water were supplemented ad libitum. Body weights were monitored every five days and blood samples were obtained at 25 days for assessment of blood picture and antibody titers after vaccination, total cholesterol and triglycerides concentrations and activity levels of alanine aminotransferase (ALT), aspartate aminotransferase (AST) and alkaline phosphatase (ALP) were estimated. At 30 days age, T3 group broiler checks reported higher body weights than other groups. Total number of white and red blood cells, hemoglobin concentration, hematocrit levels and ratio of heterocytes to lymphocytes increased significantly in treated groups, whereas significant decline of cholesterol and triglycerides concentrations as well as ALT and AST levels were shown in T3 group broiler checks. Significant increase was shown in the levels of antibody titers against both Newcastle (ND) and infectious bursal disease (IBD) vaccines. In conclusion, treatment of broiler checks early with garlic juice increase broiler performance and immune response against vaccination program and may be protect the broilers from heat stress.
\end{abstract}

Keywords: Garlic juice, Broilers, Immune response, Heat stress, Body weight, ALT, AST

Available online at http://www.vetmedmosul.org/ijvs

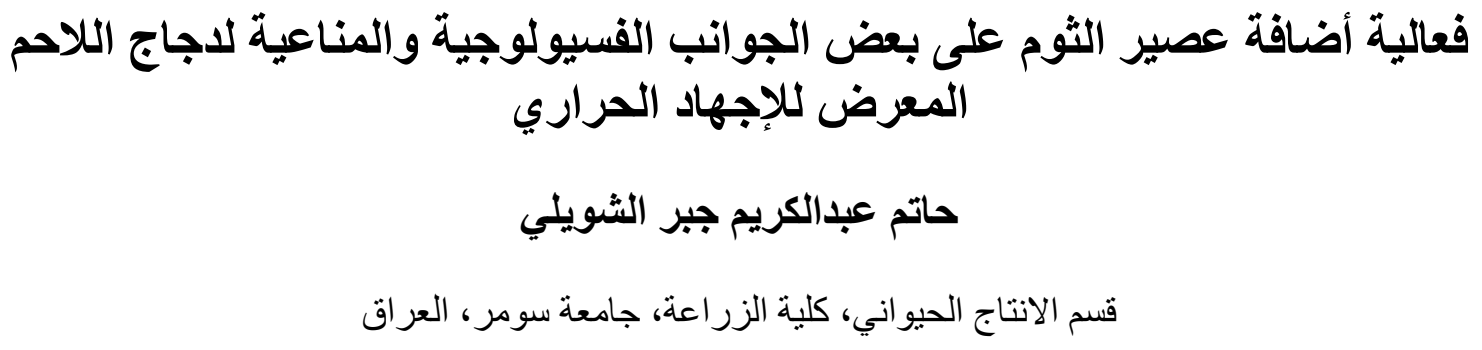

هدفت الدر اسة الحالية إلى التعرف على تأثثر أضافة عصير الثوم مع ماء الثرب لإجاج الثاب اللحم المعرض للإجهاد الحراري على الأداء

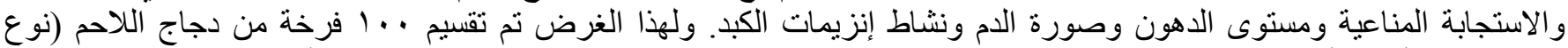

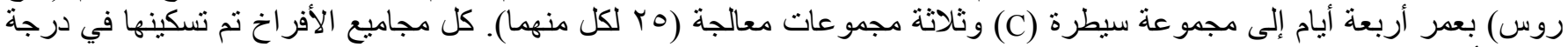

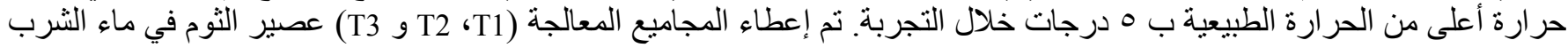

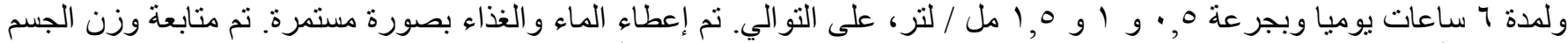

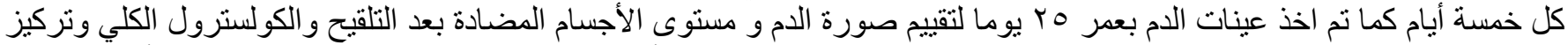

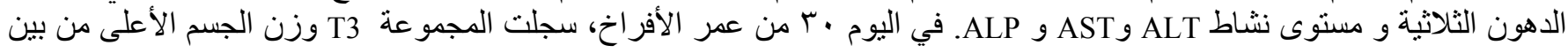




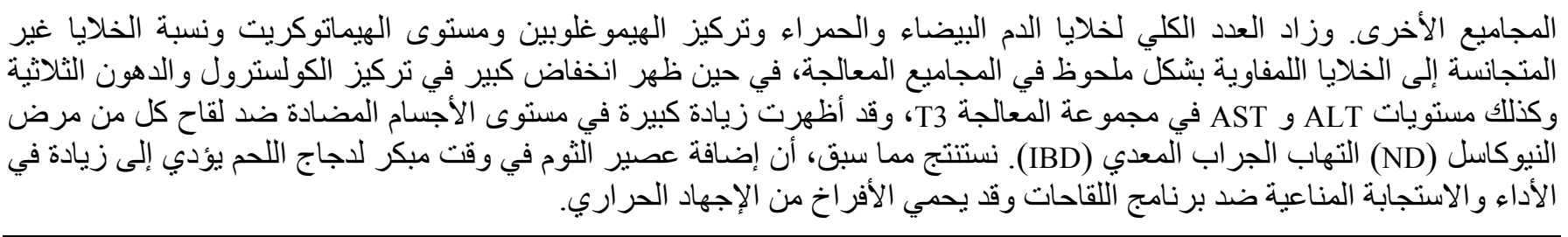

\section{Introduction}

In poultry farm, there is increase insistence to use antibiotics as food additive as growth promoter, increase performance of broilers and for treatment of many bacterial diseases (1). However, the public health is affected due to the low doses of antibiotics which have been used as food additive in animal production farm, where this addition could develop bacterial resistance to the antibiotics in humans (2). Therefore, since 2006 European Union restricted the use of antibiotics as additive in animal (3). Thus, decreased performance and increased incidence of diseases in poultry population were produced as a result to antibiotics restriction in animal food. Many researchers have been used growth promoters of natural origin like organic acids, enzymes, essential oils of some plants, probiotics and yeast cultures to provided a new, safe and cheep growth promoter to recompense the use of antibiotics in animal food $(4,5)$.

Garlic (Allium sativum), a member of family Alliaceae which was used as a spice, has antibacterial, antiinflammatory, antioxidant and antifungal effects $(6,7)$. The major medical impact effects of garlic appear to be due to the sulfur containing compounds, minerals and enzymes. The sulfur compounds in garlic are of two types, the Salkylcysteine sulfoxides and the $\gamma$-glutamyl-salkylcysteines, which are presented in equal quantities. The most important and presented in high quantity in garlic sulfur compound is alliin (8). Garlic preparation by crushing or mincing resulting in activation of alliin by allinase which is amino acid present in intact garlic to produce allicin which is the main thiosulfanate compound in the garlic and has a half life 16 hours at $25^{\circ} \mathrm{C}$ or 2.5 days when kept as juice or crushed, also, $\mathrm{pH}$ less than 3.5 or high environmental temperature make the allinase enzyme inactive and one minute in microwave is sufficient to inactivate this enzyme which is responsible for thiosulfanate conversion (9).

In broilers, it was mention that garlic, can be used as feed additive, increase chicken growth and feed conversion ratio and improve vitality Tollba and Hassan (10). Amagase et al. (11) and Demir et al. (12) reported that modulate of poultry performance and carcass merits can be improved by adding garlic powder to the poultry diets. Lewis et al. (13) showed that addition of plant extracts to broilers' diet has some effects on performance and microbial activity of intestinal tract but, none of them were significant. Moreover, Cho et al. (14) concluded that allicin has immune-stimulatory effect on birds. Demir et al. (12) attributed the strong stimulating effect of garlic to the immune system of broilers primarily to the bioactive components of garlic together with sulphur containing compounds such as alliin and allicin.

Sanjeev et al. (15) suggested that garlic powder should be added to the poultry diets because they find this addition improve growth and increase poultry tolerance to the stress of environmental sources. Garlic extract (allicin) supplementation at $50 \mathrm{mg} / \mathrm{kg}$ has an economic importance by increase feed conversion ratio, improve blood constituents parameters and chicken performance if it is used at recommended dose (16).

The present study was conducted to investigate the impact of fresh garlic juice supplementation with drinking water on some physiological and immunological aspects of broiler chicks exposed to heat stress.

\section{Materials and methods}

This study was carried out at the animal house of the College of Agriculture, University of Sumer, Iraq during the period extended from October 10, 2016 to February 1, 2017.

\section{Preparation of the extract}

Garlic was purchased from local market of Al-Refaa city. Garlic juice was prepared daily by rinsing suitable amount of the peeled garlic bulb in a ream with equal amount of distilled water quantity $\mathrm{w} / \mathrm{v}$ and the resulted juice was incubate in $37{ }^{\circ} \mathrm{C}$ overnight then filtrated and the aqueous part was used directly with drinking water of treated groups (17).

\section{Broiler checks}

One hundred unsexed one day old Ross chicks were used in this experiment. Broiler checks were housed in ventilated clean cages $(120 * 100 * 40 \mathrm{~cm}$ length, widen and height respectively) 25 bird per cage, and the temperature was $35^{\circ} \mathrm{C}$ using electrical heater with automatic thermostat. Food and water were supplied ad-libitum. The chicks were vaccinated against most common infectious diseases in Iraq, Newcastle, avian Influenza and Infectious Bursal disease. Commercial starter and grower diets (compose 
from corn, soybean, multivitamin, minerals, Di-calcium, Methionine, Lysine, choline chloride, and vegetable oil with crude protein $23 \%$ and digestible energy $3010 \mathrm{Kcal} / \mathrm{kg}$ for starter and crude protein $21 \%$ and $3100 \mathrm{Kcal} / \mathrm{kg}$ for grower) from Al-Waha Co., Iraq was used as basal diet. Food and water were supplied ad-libitum.

\section{Experimental design}

One hundred unsexed one day old Ross chicks were vaccinated against most common infectious diseases Newcastle, avian Influenza and Infectious Bursal disease (Intervet. Holland). The experimental periods were extended for 30 days. The broiler checks were individually weighed and randomly allocated into four groups (25 chicks each). All group checks were housed at $5{ }^{\circ} \mathrm{C}$ above normal ambient temperature during the experiment. First group broiler checks were fed on basal diet and served as control group. Second (T1), third (T2) and fourth (T3) groups were fed on the basal diet and And received drinking water contains garlic juice daily for 6 hours at dose $0.5,1$ and $1.5 \mathrm{ml} / 1$ respectively. Broiler checks were weighed initially and every 5 days interval. Wing blood samples were obtained at the end of experiment for assessment of total $\mathrm{RBC}, \mathrm{Hb}$ and differential $\mathrm{WBC}$ count (18). ALT, AST, ALP (19), total cholesterol (20) and Triglyceride (21) concentrations were assessed using spectrophotometric methods. Immune response was measured using ELISA technique according to manufactured procedure (ElabScience Co., China). Total protein and albumen were measured according to method described by Trinder (22) and Doumas et al. (23), respectively.

\section{Statistical analysis}

The results were expressed as mean $\pm \mathrm{SD}$. One way analysis of variance (ANOVA1) and Newman-Keuls were used to compare between experimental groups. Difference at a level of $\mathrm{p}<0.05$ was considered as significant. Statistical analysis was performed using the GraphPad Prism-version 5 (GraphPad Software, Inc. California, USA).

\section{Results}

The result in table (1) showed significant increase in body weight of T3 group checks compared with other groups which showed insignificant $(\mathrm{p} \geq 0.05)$ differences when compared between each other. The insignificant elevation started earlier at day 5 but it became significant $(\mathrm{p} \leq 0.05)$ at day 20 of broiler age.

The results showed that the total number of $\mathrm{WBC}$ and RBC counts of T3 group checks increased significantly $(\mathrm{p} \leq 0.05)$ compared with other groups (table 2). Also T2 group checks recorded higher number than $\mathrm{T} 1$ and control group checks, which was significantly lower than that of $\mathrm{T} 1$. Hemoglobin $(\mathrm{Hb})$ concentrations of $\mathrm{T} 3$ and $\mathrm{T} 2$ group checks showed insignificant $(\mathrm{p} \geq 0.05)$ difference between each other, but they were significantly $(\mathrm{p} \leq 0.05)$ higher than control and $\mathrm{T} 1$ group checks. In T3 group checks, the hematocrit (PCV) results showed significant $(\mathrm{p} \leq 0.05)$ increase than other groups, while T2 group checks recorded the lowest value among experimental groups, whereas $\mathrm{T} 1$ and control group checks recorded insignificant $(\mathrm{p} \geq 0.05)$ difference between each other. In all treated group checks, the ratio between heterophils and lymphocytes showed significant $(\mathrm{p} \leq 0.05)$ decrease compared with that of control, however in T3 group, the lowest value was recorded.

Table (3) showed significant $(\mathrm{p} \leq 0.05)$ decrease in cholesterol levels of treated groups compared to that of control, also triglyceride concentration showed significant $(p \leq 0.05)$ decrease in T3 group among experimental groups. Total protein levels showed insignificantly $(\mathrm{p} \geq 0.05)$ difference among experimental groups, however, albumen concentration was significantly $(\mathrm{p} \leq 0.05)$ increase in treated groups compared to that of control group.

The results in the present study showed significant $(p \leq 0.05)$ decrease in the activities of ALT, AST and ALP in all treated groups compared to that of control group (table 4). On the other hand, the results of immune response measured by ELISA showed significant $(p \leq 0.05)$ increase in the antibody titers against ND and IBD in T3 and T2 group checks compared to that of $\mathrm{T} 1$ and control group checks, which showed insignificant $(\mathrm{p} \geq 0.05)$ difference between each other (table 5).

Table 1: Body weight changes (gm) in control and garlic juice treated broiler checks

\begin{tabular}{ccccc}
\hline \multirow{2}{*}{$\begin{array}{c}\text { Age } \\
\text { (days) }\end{array}$} & \multicolumn{4}{c}{ Groups } \\
\cline { 2 - 5 } & $\mathrm{C}$ & $\mathrm{T} 1$ & $\mathrm{~T} 2$ & $\mathrm{~T} 3$ \\
\hline 5 & $134 \pm 5 \mathrm{a}$ & $133 \pm 4 \mathrm{a}$ & $135 \pm 3 \mathrm{a}$ & $136 \pm 5 \mathrm{a}$ \\
10 & $245 \pm 4 \mathrm{a}$ & $246 \pm 4 \mathrm{a}$ & $250 \pm 6 \mathrm{a}$ & $256 \pm 8 \mathrm{a}$ \\
15 & $530 \pm 6 \mathrm{a}$ & $532 \pm 8 \mathrm{a}$ & $537 \pm 10 \mathrm{a}$ & $540 \pm 15 \mathrm{a}$ \\
20 & $854 \pm 10 \mathrm{c}$ & $870 \pm 10 \mathrm{~b}$ & $875 \pm 13 \mathrm{~b}$ & $910 \pm 18 \mathrm{a}$ \\
25 & $1126 \pm 20 \mathrm{c}$ & $1187 \pm 11 \mathrm{~b}$ & $1185 \pm 18 \mathrm{~b}$ & $1270 \pm 25 \mathrm{a}$ \\
30 & $1750 \pm 25 \mathrm{~b}$ & $1760 \pm 20 \mathrm{~b}$ & $1791 \pm 30 \mathrm{~b}$ & $1910 \pm 20 \mathrm{a}$ \\
\hline
\end{tabular}

Values were expressed as mean \pm SD $(n=15$ of broiler chicks), Different small letters refer to significant differences $(p<0.05)$ between groups for each period, C (control broiler checks): supplemented with water and food without any addition, T1 (treatment group-1): supplemented with $0.5 \mathrm{ml}$ of garlic juice/L of drinking water daily for $6 \mathrm{hr}$ a day, T2 (treatment group-2): supplemented with $1 \mathrm{ml}$ of garlic juice/L of drinking water daily for $6 \mathrm{hr}$ a day, T3 (treatment group-3): supplemented with $1.5 \mathrm{ml}$ garlic juice/L of drinking water daily for $6 \mathrm{hr}$ a day. 
Table 2: Blood parameters changes in control and garlic juice treated broiler checks

\begin{tabular}{lcccc}
\hline \multirow{2}{*}{ Parameters } & \multicolumn{4}{c}{ Groups } \\
\cline { 2 - 5 } & $\mathrm{C}$ & $\mathrm{T} 1$ & $\mathrm{~T} 2$ & $\mathrm{~T} 3$ \\
\hline $\mathrm{WBC}$ & $24 \pm$ & $24.3 \pm$ & $24.8 \pm$ & $25 \pm$ \\
$(1000 / \mathrm{ml})$ & $0.3 \mathrm{~d}$ & $0.2 \mathrm{c}$ & $0.3 \mathrm{~b}$ & $0.1 \mathrm{a}$ \\
$\mathrm{RBC}$ & $2.36 \pm$ & $2.37 \pm$ & $2.57 \pm$ & $2.59 \pm$ \\
$\left(10^{*} 12\right) \mathrm{L}$ & $0.02 \mathrm{c}$ & $0.03 \mathrm{~b}$ & $0.02 \mathrm{a}$ & $0.03 \mathrm{a}$ \\
$\mathrm{Hb}$ & $10.5 \pm$ & $11.4 \pm$ & $9.9 \pm$ & $11.4 \pm$ \\
$\mathrm{g} / \mathrm{dl}$ & $0.01 \mathrm{~b}$ & $0.02 \mathrm{a}$ & $0.01 \mathrm{c}$ & $0.02 \mathrm{a}$ \\
$\mathrm{HCT}$ & $27.3 \pm$ & $27.7 \pm$ & $26 \pm$ & $29.9 \pm$ \\
$\mathrm{H} / \mathrm{L}$ & $0.01 \mathrm{~b}$ & $0.03 \mathrm{~b}$ & $0.02 \mathrm{c}$ & $0.02 \mathrm{a}$ \\
ratio & $0.27 \pm$ & $0.23 \pm$ & $0.23 \pm$ & $0.21 \pm$ \\
\hline
\end{tabular}

Values were expressed as mean \pm SD $(n=15$ of broiler chicks), Different small letters refer to significant differences $(p<0.05)$ between groups for each period, $C$ (control broiler checks): supplemented with water and food without any addition, T1 (treatment group-1): supplemented with $0.5 \mathrm{ml}$ of garlic juice/L of drinking water daily for $6 \mathrm{hr}$ a day, T2 (treatment group-2): supplemented with $1 \mathrm{ml}$ of garlic juice/L of drinking water daily for $6 \mathrm{hr}$ a day, T3 (treatment group-3): supplemented with $1.5 \mathrm{ml}$ garlic juice/L of drinking water daily for $6 \mathrm{hr}$ a day.

Table 3: Lipid profile changes in control and garlic juice treated broiler checks

\begin{tabular}{lcccc}
\hline \multirow{2}{*}{ Parameters } & \multicolumn{4}{c}{ Groups } \\
\cline { 2 - 5 } & $\mathrm{C}$ & $\mathrm{T} 1$ & $\mathrm{~T} 2$ & $\mathrm{~T} 3$ \\
\hline $\begin{array}{l}\text { Cholesterol } \\
\text { mg/100ml }\end{array}$ & $200 \pm 6 \mathrm{a}$ & $135 \pm 5 \mathrm{~b}$ & $130 \pm 3 \mathrm{~b}$ & $124 \pm 2 \mathrm{c}$ \\
$\begin{array}{l}\text { Triglycerides } \\
\text { mg/100ml }\end{array}$ & $183 \pm 3 \mathrm{a}$ & $182 \pm 2 \mathrm{a}$ & $182 \pm 3 \mathrm{a}$ & $167 \pm 4 \mathrm{~b}$ \\
$\begin{array}{l}\text { Total protein } \\
\text { g/dl }\end{array}$ & $5.6 \pm 1 \mathrm{a}$ & $5.5 \pm 1 \mathrm{a}$ & $5.7 \pm 1 \mathrm{a}$ & $5.7 \pm 1 \mathrm{a}$ \\
$\begin{array}{l}\text { Albumin } \\
\text { g/dl }\end{array}$ & $3.8 \pm 1 \mathrm{~b}$ & $4.9 \pm 1 \mathrm{a}$ & $4.8 \pm 1 \mathrm{a}$ & $4.9 \pm 1 \mathrm{a}$ \\
\hline
\end{tabular}

Values were expressed as mean \pm SD $(n=15$ of broiler chicks), Different small letters refer to significant differences $(p<0.05)$ between groups for each period, $C$ (control broiler checks): supplemented with water and food without any addition, T1 (treatment group-1): supplemented with $0.5 \mathrm{ml}$ of garlic juice/L of drinking water daily for $6 \mathrm{hr}$ a day, T2 (treatment group-2): supplemented with $1 \mathrm{ml}$ of garlic juice/L of drinking water daily for $6 \mathrm{hr}$ a day, T3 (treatment group-3): supplemented with $1.5 \mathrm{ml}$ garlic juice/L of drinking water daily for $6 \mathrm{hr}$ a day.
Table 4: Liver enzyme activities in control and garlic juice treated broiler checks

\begin{tabular}{lcccc}
\hline \multirow{2}{*}{ Parameters } & \multicolumn{4}{c}{ Groups } \\
\cline { 2 - 5 } & $\mathrm{C}$ & $\mathrm{T} 1$ & $\mathrm{~T} 2$ & $\mathrm{~T} 3$ \\
\hline AST $\mu / \mathrm{L}$ & $9 \pm 0.5 \mathrm{a}$ & $6 \pm 0.5 \mathrm{~b}$ & $7 \pm 0.5 \mathrm{~b}$ & $5 \pm 0.5 \mathrm{c}$ \\
ALT $\mu / \mathrm{L}$ & $29 \pm 2 \mathrm{a}$ & $30 \pm 3 \mathrm{a}$ & $32 \pm 2 \mathrm{a}$ & $33 \pm 4 \mathrm{a}$ \\
ALK $\mu / \mathrm{L}$ & $1767 \pm 11 \mathrm{a}$ & $899 \pm 8 \mathrm{~b}$ & $681 \pm 10 \mathrm{c}$ & $461 \pm 9 \mathrm{~d}$ \\
AST $\mu / \mathrm{L}$ & $9 \pm 0.5 \mathrm{a}$ & $6 \pm 0.5 \mathrm{~b}$ & $7 \pm 0.5 \mathrm{~b}$ & $5 \pm 0.5 \mathrm{c}$ \\
\hline
\end{tabular}

Values were expressed as mean \pm SD $(n=15$ of broiler chicks), Different small letters refer to significant differences $(p<0.05)$ between groups for each period, $C$ (control broiler checks): supplemented with water and food without any addition, T1 (treatment group-1): supplemented with $0.5 \mathrm{ml}$ of garlic juice/L of drinking water daily for $6 \mathrm{hr}$ a day, T2 (treatment group-2): supplemented with $1 \mathrm{ml}$ of garlic juice/L of drinking water daily for $6 \mathrm{hr}$ a day, T3 (treatment group-3): supplemented with $1.5 \mathrm{ml}$ garlic juice/L of drinking water daily for $6 \mathrm{hr}$ a day.

Table 5: Immune response changes in control and garlic juice treated broiler checks

\begin{tabular}{lcccc}
\hline \multirow{2}{*}{ Parameters } & \multicolumn{4}{c}{ Groups } \\
\cline { 2 - 5 } & $\mathrm{C}$ & $\mathrm{T} 1$ & $\mathrm{~T} 2$ & $\mathrm{~T} 3$ \\
\hline \multirow{2}{*}{ ND. } & $868 \pm 15$ & $850 \pm 20$ & $1316 \pm 20$ & $1460 \pm 13$ \\
& $\mathrm{c}$ & $\mathrm{c}$ & $\mathrm{b}$ & $\mathrm{a}$ \\
\multirow{2}{*}{ IBD } & $990 \pm 12$ & $1030 \pm 15$ & $1190 \pm 25$ & $1135 \pm 35$ \\
& $\mathrm{~b}$ & $\mathrm{~b}$ & $\mathrm{a}$ & $\mathrm{a}$ \\
\hline
\end{tabular}

Values were expressed as mean \pm SD ( $n=15$ of broiler chicks), Different small letters refer to significant differences $(p<0.05)$ between groups for each period, $C$ (control broiler checks): supplemented with water and food without any addition, T1 (treatment group-1): supplemented with $0.5 \mathrm{ml}$ of garlic juice/L of drinking water daily for $6 \mathrm{hr}$ a day, T2 (treatment group-2): supplemented with $1 \mathrm{ml}$ of garlic juice/L of drinking water daily for $6 \mathrm{hr}$ a day, T3 (treatment group-3): supplemented with $1.5 \mathrm{ml}$ garlic juice/L of drinking water daily for $6 \mathrm{hr}$ a day.

\section{Discussion}

The results of present study were in agreement with other studies $(16,17,24-26)$ who found that supplementation of garlic to the broiler food has a positive effect on body weight. Also, this finding disagreed with (27) who found that the adding of garlic powder to the broiler food at different levels has no significant $(p \geq 0.05)$ effect on the body weight of the chicks. The positive role of allicin on the performance of intestinal flora may be the cause of improving digestion and feed conversion ratio (28) in addition to the antibacterial effect of garlic on different types of pathogenic bacteria which is indirectly increase 
feed conversion ratio (29). The role of garlic acid in the enhancement of enzymes activity of pancreas which will provide a suitable environment for food absorption may be another cause for this result (30).

The present findings were in harmony with the results obtained by Oleforuh-Okleh et al. (31) who found that treatment with garlic and ginger in birds will significantly increase $\mathrm{WBC}, \mathrm{RBC}, \mathrm{PCV}$ and $\mathrm{Hb}$, also, Elnagar et al. (32) found that the adding of garlic extract to the birds diet produce significant increase in the number of RBC. Therefore, it can be suggested that the increase in body weight may be due to the improving in oxygen carrying capacity of this constituents of the blood resulting in maximal availability of nutrients to the chicks. Jamroz et al. (33) suggested that the increase in the number of WBC is due to the bacteria static effect of garlic extract especially on Salmonella spp and E-coli which lead to produce large number of WBC due to abundance of low pathogenic antigen.

Moreover, the improvement in the chick immune system may be due to the immunostimulatory effect of garlic juice which cause significant decrease in the $\mathrm{H} / \mathrm{L}$ ratio especially that shown in $\mathrm{T} 3$ group checks. This result was in agreement with that of Eid and Iraqi (34) and Mohamed et al. (16) who observed significant increase in the number of lymphocyte in the broiler chicks supplied with garlic extract which could be the cause of decreased $\mathrm{H} / \mathrm{L}$ ratio.

The results of lipid profile, shown in the present study, were in agreement with that of previous studies (16,33-36) who found that garlic supplementation has a hypocholesterolemic effect in treated birds. Garlic exhibit this effect may be due to its possible role in the inhibition of most important enzymes in cholesterol and lipid synthesis such as cholesterol $7 \alpha$-hydroxylase, fatty acid synthetase and hepatic 3-hydroxy-3-methylglutaryl coenzyme A reductase (15).

Many researchers reported that garlic or its extract supplementation has a protective effect on hepatocytes which will cause significant $(p \leq 0.05)$ decrease in the activity of liver enzymes $(15,16,37)$. Generally the lowest enzyme activity was recorded in serum of broiler chicks of group T3. These results can be attributed to garlic juice supplementation which act as stabilizer to liver cell membrane and prevent the harmful effect of the deleterious agent and free radicals.

During vaccination, when the antigen enters the body, the macrophages ingest the antigen and then display a portion of the antigen on its membrane, which stimulates the B-lymphocytes to produce the antibodies. The macrophages also produce interleukin-1, Interferon $\gamma$ and $\alpha$, which stimulate B lymphocytes to produce antibodies. Tlymphocytes are differentiated and divided to affect $\mathrm{T}$ cells and helper $\mathrm{T}$ cells, which meet the antigen presented on the macrophage membrane. As a result of IL-1 stimulation, Interleuken-2 (IL-2) stimulates the response of Blymphocytes, which produce antibody type IgM, which converts them into B-lymphocytes producing IgG antibodies (38). Garlic has an important role in this mechanism by stimulating division and differentiation of lymphocyte and macrophage, also, activate phagocytosis, IL-2 and $\gamma$ interferon production $(39,40)$. These results were in agreement with that of Mohamed et al. (16) who found that dietary supplementation of garlic improved phagocytosis and immune response.

In conclusion garlic juice supplementation to broiler drinking water at a dose of $1.5 \mathrm{ml} / \mathrm{L}$ daily for 6 hours a day for 30 days will increase body weight, immune response, protect liver cells against harmful effect of Heat stress and improve blood picture constituent.

\section{References}

1. Brenes A, Roura E. Essential oils in poultry nutrition: Main effects and modes of action. Anim Feed Sci Technol. 2010;158:1-14.

2. Yang Y, Iji PA, Choct M. Dietary modulation of gut microflora in broiler chickens: A review of the role of six kinds of alternatives to infeed antibiotics. Worlds Poult Sci J. 2009;65:97-114.

3. Michard J. Seeking new broiler growth promoters. Poult Int. 2008;47:28-30.

4. Hooge DM. Dietary alternative for improving live performance of antibiotic-free poultry Zootec Int. 2006;3:42-51

5. Ayasan T. Effects of dietary inclusion of protexin (probiotic) on hatchability of Japanese quails. Indian J Anim Sci. 2013;83(1):78-81.

6. Vaidya V, Keith UI, Derek AP. Garlic, source of the ultimate Antioxidants-Sulfenic acids. Angew Chem. 2009;121(1):163-166.

7. Block E, Dane AJ, Thomas S, Cody RB. Applications of direct analysis in real time-mass spectrometry (DART-MS) in allium chemistry. Spectrometry and 2 propenesulfinic acids, diallyl trisulfane S-oxide and other reactive sulfur compounds from crushed garlic and other alliums. J Agr Food Chem. 2010;58(8):461-725.

8. Lawson LD. Garlic: a review of its medicinal effects and indicated active compounds. In: L. D. Lawson and R. Bauer, Editors, Phytomedicines of Europe: Chemistry and Biological Activity, ACS Symposium Series 691. American Chemical Society, Washington, DC. 1998; pp: 176-209.

9. Pedraza-Chaverri J, Medina-Campos O, N.Segoviano-Murillo S. Effect of heating on peroxynitrite capacity of garlic. Food and Chemical Toxicology, In Press, Corrected Proof, Available online 24 October 2006.

10. Tollba AAH, Hassan MSH. Using some natural additives to improve physiological and productive performance of broiler chicks under high temperature conditions. Black cumin (Nigella sativa) or Garlic (Allium sativum). Poult Sci. 2003;23:327-340.

11. Amagase H, Petesch BL, Matsuura H, Kasuga S, Itakura Y. Recent advances on the nutritional effects associated with the use of garlic as a supplement intake of garlic and its bioactive components, J Nutr. 2001;131(S):955-962.

12. Demir E, Sarica S, Ozcan MA, Suicmez M. The use of natural feed additives as alternatives for an antibiotic growth promoter in broiler diets. Br Poult Sci. 2003;44(S):44-45.

13. Lewis MR, Rose SP, Mackenzie AM and Tucker LA. Effects of dietary inclusion of plant extracts on the growth performance of male broiler chickens. Br Poult Sci. 2003;44:S43-S44. 
14. Cho SJ, Rhee DK, Pyo S. Allicin, a major component of garlic, inhibits apoptosis of macrophage in a depleted nutritional state. J Nutr. 2006;22(11-12):77-84.

15. Sanjeev K, Ashok K, Astha C. Alteration in serum biochemical parameters due to garlic (Allium sativum) supplementation in broilers diets. Afr J Biotech. 2013;12(29):4691-4698.

16. Mohamed IE, Mosad AS, Mohamed MS, Adel H. Growth performance, immune response, Blood serum parameters, Nutrient digestibility and carcass traits of broiler chicken as affected by dietary supplementation of Garlic extract (Allicin). Alex J Vet Sci. 2016;49(2):50-64.

17. Afsharmanesh M, Sadeghi RB, Mehrabadi M. The comparison of natural feed additives (garli $\mathrm{c}$ and yogurt) with antibiotic growth promoters on broiler performance, 1st national conference livestock and poultry industry of Golestan province. 2008;208:25-36.

18. Bergmayer HU, Bernt E. Methods of enzymatic analysis. Verlag Chemie, Weinheim, Academic Press, London 1974.

19. Tietz NW. Fundamentals of Clinical Chemistry.WB. Saunders Company. USA. 1970.

20. Verley H. Practical Clinical Biochemistry.4rth ed. WB. Saunders Company, Philadelphia, USA. 1975.

21. Tietz NW. Fundamentals of Clinical Biochemistry. 3rd ed. W. B. Saunders Company, USA. 1998.

22. Trinder P. Determination of glucose in blood using glucose oxidase with alternative oxygen acceptor. Anim Clin Biochem.1969;6:24.

23. Doumas BT, Bayso DD, Carter RJ, Peters T, Schaffer R. Determination of total serum protein. Clin Chem. 1981;27:1642-1643.

24. Kumar M, Choudhary RS, Vaishnav JK. Effect of supplemental prebiotic, probiotic and turmeric in diet on the performance of broiler chicks during summer. Ind J Poult Sci. 2005:40(2):137-141.

25. Raeesi M, Hoseini -Aliabad AS, Roofchaee A, Zare Shahneh A, Piral S. Effect of Periodically Use of Garlic (Allium sativum) Powder on performance and Carcass Characteristics in Broiler Chickens. World Acad. Sci. 2010;1213-1219.

26. Mansoub H, Nezhad M. The effects of using Thyme, Garlic an Nettle on performance, carcass quality and blood parameters. Annals biol Res. 2011;2(4):315-320.

27. Onibi EG, Adebisi EO, Fajemisin NA, Adetunji VA. Response of broiler chickens in terms of performance and meat quality to garlic (Allium sativum) supplementation. Afr J Agricul Res. 2009;4(5):511517.

28. Pourali M, Mirghelenj SA, Kermanshashi D. Effect of garlic powder on productive Performance and immune response of broiler chickens challenged with Newcastle disease virus. Global Veterinaria. 2010;4:616-621.

29. Onu PN, Aja PM. Growth performance and haematological indices of weaned Rabbits fed garlic (Allium sativum) and ginger (Zingiber officinale) supplemented diets. Inter J Food Agric Vet Sci. 2011;1:5159.

30. Ramakrishna RR, Platel K, Srinivasan K. In-vitro influence of species and spice active principles on digestive enzymes of rat pancreas and small intestine. Nahrung. 2003;47:408-412.

31. Oleforuh-Okoleh VU, Chukwu GC, Adeolu AI. Effect of ground ginger and garlic on the growth performance, carcass quality and economics of production of broiler chickens. Global J. Bio-Sci. Biotechnol. 2014;3:225-229.

32. Elnagar SA, El-Sebai A, Abaza M. Efficacy of (Allii) against fattening in peckin ducks, 2nd World Waterfowl Conference, Egypt 2003.

33. Jamroz D, Orda J, Kamel C, Wilicziewicz A, Wertelecki T, Skorupinska J. The influence of phytogenic extracts on performance, nutrient digesti-bility, carcass characteristics, and gut microbial status in broiler chickens, J Anim Feed Sci. 2003;12:583-596.

34. Eid KM, Iraqi MM. Effect of garlic powder on growth performance and immune response for Newcastle and avian influenza virus diseases in broiler of chickens, 2nd International Conference on Biotechnology Applications in Agriculture (ICBAA), Benha University, Moshtohor and Hurghada, 8-12, April 2014, Egypt.

35. Mansoub NH. Comparative effects of using garlic as probiotic on performance and serum composition of broiler chickens. Ann Boil Res. 2011;2:486-490.

36. Stanacev V, Glamocic D, Milosevic N, Puvaca N, Stanacev V, Plavsa N. Effect of garlic (Allium sativum L.) infattening chicks nutrition. Afr J Agricul Res. 2011;6:943-948.

37. Kumar S, Kumar A, Chandra A. Alteration in serum biochemical parameters due to garlic (Allium sativum) supplementation in broilers' diets, Afr J Biotechnol. 2013;12(29):4691-4698.

38. Sheffy BE, Schultz RD. Influence of vitamin and selenium on immune response mechanisms. Federation proceedings. 1979;38:2139.

39. Lamm DL, Riqqs DR. Enhanced immunocompetence by garlic: Rolein bladder cancer and malignancies J Nutr. 2001;131(35):675705.

40. Kyo E, Uda N, Kasuga S, Itakura Y. Immunomodulatory effects of aged garlic extract. J Nutr. 2001;131:1075-1079. 